\title{
Thyroid and Sex Hormones in Serum of Pregnant and Non Pregnant Camels (Camelus dromedaries)
}

\author{
Amal M. Abo El-Maaty", Mahmoud A.I. Elgabry ${ }^{*}$, Faten, I. \\ Gabr **, Omima H. Ezzo" \\ *Animal Reproduction and Artificial Insemination Department, \\ Veterinary Research Division, National Research Centre, and \\ **Animal Reproduction Research Institute, Agriculture \\ Research Centre, Cairo, Egypt.
}

\begin{abstract}
7 HIS STUDY describes difference in thyroid hormones and sex hormones in pregnant and non pregnant camels. Female camels $(n=12)$ of different ages brought from Sudan and belonged to a private camel farm underwent rectal ultrasound scanning for detection of early pregnancy. Male and females were kept together in the same barn during the breeding season. Blood was collected and subjected to hormonal analysis. Estradiol, progesterone, testosterone, $\mathrm{T}_{3}$, and $\mathrm{T}_{4}$ Insulin were assayed. Results revealed that levels of $T_{3}$ and $T_{4}$ were significantly high in pregnant camels. While, low significant $\mathrm{T}_{4}: \mathrm{T}_{3}$ was observed in pregnant camels. Progesterone levels significantly increased in pregnant camels and its values ranged from 2.83 to 6.89 $\mathrm{ng} / \mathrm{ml}$. Both testosterone and estradiol slightly increased during early pregnancy. In conclusion, progesterone still the most important confirmatory hormone for detecting pregnancy in camels even thought after the advent of ultrasound examination because pregnancy can't be detected by either trans-rectal ultrasound or rectal palpation beyond 90 days of gestation. It appeared that thyroid hormones play important role during camel's gestation.
\end{abstract}

Keywords: Pregnancy, Insulin like growth factor-I, Thyroid hormones, Steroid hormones, Camels.

Light colored camels in Egypt are one humped. Most light colored camels are imported from and through Sudan (El-Wishy, 1988). The one humped camel (Camelus dromedarius) is a seasonal breeder with a relatively short breeding period, when pre-ovulatory size follicle is exhibited (Tibary and Anouassi, 1997). The breeding season starts from December to August every year in Egypt (Wilson, 1989). Regarding reproduction, all camelids are induced ovulators, usually ovulating only after mating, and if the camel does not conceive the corpus luteum has a very short lifespan of only $8-10$ days (Marie \& Anouassi, 1987 and Skidmore, 2005).

Ultrasound is being used in she-camel for studying ovarian dynamics (Skidmore et al., 1995 and Tibary \& Anouassi, 1996) and detection early pregnancy (Skidmore et al., 1992). 
Hormones, enzymes and hemograms have been described in the blood of female camels during different reproductive statuses including the estrous cycle (Elias et al., 1984 a,b and Homeida et al., 1988), pregnancy (Skidmore et al.,1996 and Zhao et al., 1998) and postpartum period (Agarwal et al., 1992).

The thyroid gland predominantly secretes the pro-hormone $\mathrm{T}_{4}$ but also produces smaller amounts of the active hormone $\mathrm{T}_{3}$. However, $\mathrm{T}_{4}$ must be activated by deiodination to $\mathrm{T}_{3}$ in order to initiate thyroid hormone action. Most plasma $T_{3}$ is derived from peripheral conversion of $T_{4}$. This reaction is catalyzed by the type 1 and 2 iodothyronine deiodinases (Bianco et al., 2002). Luteal cells of bovine mature corpora lutea are also involved in the synthesis of thyroid hormones, which may modulate progesterone synthesis, acting in an autocrine and paracrine way (Mutinati et al., 2010).

Human placenta secretes transthyretin, which is a serum transport protein for $\mathrm{T}_{4}$, into maternal and fetal circulations that can be taken up by trophoblasts and translocated to the fetal circulation (Mortimer et al., 2012).

Studies on circulating levels of Insulin Like Growth factor-I were not available in dromedary camels so the purpose of this study was to characterize its levels in blood serum of early pregnant and non pregnant camels in addition to thyroid and ovarian hormones and find out the relation between them.

Animals

\section{Material and Methods}

Twelve female camels of different ages brought from Sudan and belonged to a private camel farm underwent this study. Females were kept with males in open yards and subjected to natural day light and temperature. Camels were fed in groups and clean water was available ad libitum. Camels were scanned with endorectal ultrasound for detection of pregnancy in squatting position.

\section{Blood sampling}

Blood samples from the jugular vein of 9 pregnant from days 30 to 90 of gestation with each ultrasound examination and from 3 non-pregnant camels previously examined by ultrasound were collected in plain vacationers and were transported to laboratory. Then blood sera was harvested and stored at $-20^{\circ} \mathrm{C}$ until hormonal assay.

\section{Hormonal assay}

$\mathrm{T}_{3}$ and $\mathrm{T}_{4}$ (Monobind, Lake Forest, CA 92630, USA) were assayed using ELISA diagnostic kits. The limit of sensitivity, intra- and inter-assay coefficients

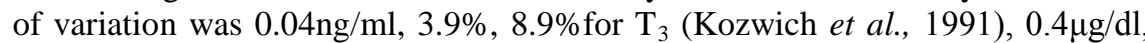
$4.4 \%, 8.3 \%$ for $\mathrm{T}_{4}$ (Charkes, 1996). Chemiluminescence Enzume immunoassay (CLIA) was used to assay estradiol (E2, Ratcliffe et al.,1988), quantitative solid phase enzyme linked immunosorbent assay (Immunospec corporation, 7018 Owensmouth Ave, Suite 103 Canoga Park, CA, 91303) was used to measure progesterone ( $\mathrm{P} 4$, Kakabakos and Khosravi, 1992) and total Testosterone Egypt. J. Vet. Sci. Vol. 45-46 (2014 - 2015) 
(Sanchez-Carbayo et al., 1998). Sensitivity, intra- and inter- assay coefficients of variation were $0.05 \mathrm{ng} / \mathrm{ml}, 6.4 \%$ and $10.9 \%$ for P4 and $5.0 \mathrm{pg} / \mathrm{ml}, 3.9 \%, 10.1 \%$ for $\mathrm{E} 2$ and $0.1 \mathrm{ng} / \mathrm{mL}, 11 \%$ and $13 \%$ for total testosterone.

\section{Statistical analysis}

Data are presented as mean \pm standard error of mean (SEM). Statistical analysis of the data was performed using SPSS $®$ software (SPSS, 2007). Data was subjected to Independent sample t-test.

\section{Results}

Pregnancy was detected from 30 to 90 days with ultrasound. Pregnancies $>90$ days were confirmed by absence of detectable non pregnant uterus and progesterone $>2 \mathrm{ng} / \mathrm{ml} . \mathrm{T}_{3}$ levels are significantly $(P=0.036)$ high in pregnant camels $(3.51 \pm 0.23)$ compared to non pregnant camels $(2.16 \pm 0.52)$. As well as $\mathrm{T}_{4}$ levels are significantly $(P=0.025)$ high $(10.24 \pm 0.31)$ in pregnant camels compared to non pregnant ones $(8.34 \pm 0.37) . \mathrm{T}_{4}: \mathrm{T}_{3}$ are significantly $(P=0.049)$ high in non pregnant camels. Mean estradiol (E2) and testosterone (Testo) are not significantly different between pregnant and non pregnant camels, but their levels slightly increased in pregnant camels (Table 1). Progesterone (P4) levels increased significantly $(P=0.007)$ in pregnant camels $(4.60 \pm 0.40)$ and its values ranged from 2.83 to $6.89 \mathrm{ng} / \mathrm{ml}$.

TABLE 1. Mean concentrations of IGF-I, T3, T4, Progesterone (P4), estradiol (E2) and testosterone (Testo) in serum of pregnant and non pregnant camels.

\begin{tabular}{|l|c|c|c|c|c|c|}
\hline \multirow{2}{*}{ Hormone } & \multicolumn{3}{|c}{ Non pregnant } & \multicolumn{3}{c|}{ Pregnant } \\
\cline { 2 - 8 } & Mean \pm SEM & Min. & Max. & Mean \pm SEM & Min. & Max. \\
\hline IGF-I $(\mathrm{ng} / \mathrm{mL})$ & $597.52 \pm 45.26$ & 552.26 & 642.78 & $475.71 \pm 61.17$ & 269.34 & 725.96 \\
\hline $\mathrm{T}_{3}(\mathrm{ng} / \mathrm{mL})^{*}$ & $2.16 \pm 0.52$ & 1.65 & 2.68 & $3.51 \pm 0.23$ & 2.71 & 4.61 \\
\hline $\mathrm{T}_{4}(\mu \mathrm{g} / \mathrm{dl})^{*}$ & $8.34 \pm 0.37$ & 7.97 & 8.71 & $10.24 \pm 0.31$ & 8.90 & 11.68 \\
\hline $\mathrm{T}_{4}: \mathrm{T}_{3} *$ & $4.04 \pm 0.79$ & 3.25 & 4.85 & $3.00 \pm 0.16$ & 2.22 & 4.02 \\
\hline $\mathrm{P} 4(\mathrm{ng} / \mathrm{mL})^{* *}$ & $1.43 \pm 0.31$ & 1.12 & 1.74 & $4.60 \pm 0.40$ & 2.83 & 6.89 \\
\hline $\mathrm{E} 2(\mathrm{pg} / \mathrm{mL})$ & $349.22 \pm 1.64$ & 347.59 & 350.86 & $362.87 \pm 21.55$ & 273.35 & 488.41 \\
\hline Testo $(\mathrm{ng} / \mathrm{mL})$ & $0.31 \pm 0.19$ & 0.07 & 0.35 & $0.59 \pm 0.23$ & 0.05 & 1.96 \\
\hline
\end{tabular}

Correlation coefficients (Table 2 ) showed that levels of $\mathrm{T}_{3}$ directly correlated with $\mathrm{T}_{4}$ and this correlation is highly significant $(\mathrm{r}=0.74, P=0.006)$. Both $\mathrm{T}_{3}$ and $\mathrm{T}_{4}$ inversely correlated with estradiol and directly with both progesterone and testosterone but these correlations are considered weak and insignificant. Progesterone is directly correlated with estradiol $(\mathrm{r}=0.64, p=0.02)$. Progesterone and estradiol are directly correlated with testosterone but these correlations are also not significant. 
TABLE 2. Correlation coefficients between different hormones.

\begin{tabular}{|l|c|c|c|c|c|}
\hline & T3 & T4 & P4 & E2 & T4 \\
\hline IGF-1 & 0.13 & 0.05 & -0.55 & -0.54 & 0.44 \\
\hline T3 & 1 & 0.74 & 0.15 & -0.30 & 0.21 \\
\hline T4 & & 1 & 0.24 & -0.31 & 0.39 \\
\hline p4 & & & 1 & 0.64 & 0.21 \\
\hline E2 & & & & 1 & 0.28 \\
\hline
\end{tabular}

* correlation is significant at $P<0.05, * *$ correlation is significant at $P<0.01$.

\section{Discussion}

The dromedary or one-humped camel is a ruminant but it has a diffuse epitheliochorial placenta like that of pigs and horses (van Lennep, 1963, Shalash and Nawito, 1963).

It is induced ovulator (Chen et al., 1985, Anouassi et al., 1992) and the corpus luteum that develops after a sterile mating has a life span of only 8-10 days (Musa and Abusineina, 1978, Marie and Anouassi, 1987, Sumar, 2000). The ovulation and luteal phases are induced only in bred females, while un-bred females remain unovulated and display follicular phase only (Martin, 2004).

\section{Sex hormones}

Up till now progesterone hormone level is a very useful tool to monitor pregnancy in camels (Alfuraiji, 1998). The primary source of progesterone in the female camel is the corpus luteum. The placenta does not contribute to progesterone secretion, and all camelids depend entirely on progesterone from the corpus luteum to maintain their pregnancy (Skidmore, 2005).

The high levels of progesterone in the serum observed in the present study indicated ovulation in nine female camels due to successful mating. The present findings indicated that serum progesterone levels in the early pregnant camel remain higher than $2.0 \mathrm{ng} / \mathrm{ml}$ (2.83 to 6.89) and coincide with the ultrasound findings. Ultrasound results could only be interpreted as pregnant and non pregnant since males and females were kept together and the precise mating date was not recorded. Moreover, Camel pregnancy was not subjected to intensive research using ultrasound so no equation for determining gestational age in camels in all invented ultrasound scanners. In accordance to other studies, in dromedary camels, during the first month after mating progesterone levels ranged from 3 to $7 \mathrm{ng} / \mathrm{mL}$ (Agarwal et al., 1987 and Elias et al., 1984a) and in the early pregnant llama (3 to $4.5 \mathrm{ng} / \mathrm{mL}$ ) and the last month of pregnancy (7.4 to 9.2) compared to non-pregnant llamas where it ranged from 0.9 to $1.4 \mathrm{ng} / \mathrm{ml}$ (Adam et al., 1989). As well as plasma progesterone concentrations increased by 5 days after mating and remained elevated in pregnant llamas $(>2.0 \mathrm{ng} / \mathrm{ml})$ throughout most

Egypt. J. Vet. Sci. Vol. 45-46 (2014 - 2015) 
of pregnancy (Leon et al., 1990). Similar to the dromedary camels of the present work, serum progesterone during pregnancy in Bactrian camel increased 15 days after insemination and remained elevated throughout most of gestation with means $3.06 \pm 0.49$ to $8.51 \pm 4.80 \mathrm{ng} / \mathrm{mL}$ during early or late gestation (Zhao et al., 1998).

Concentrations of progesterone remained $<1 \mathrm{ng} / \mathrm{ml}$ throughout the estrous cycle in non pregnant dromedary camels (Homeida et al., 1988). As well as level of progesterone remains low in the absence of mating and ovulation (Ayoub et al., 2003, Skidmore, 2005, Ghazi, 2007 and Babiker et al., 2011). Recently, Ali et al. (2010) reported low values $(1.7 \mathrm{ng} / \mathrm{ml})$ of progesterone in serum of normal non pregnant camels compared to those affected with ovarian reproductive disorders. Moreover, low levels of serum progesterone $(1.2 \pm 2.0 \mathrm{ng} / \mathrm{ml})$ were recorded in serum of non pregnant camels though high progesterone levels were observed in both bursal $(1.7 \pm 0.9 \mathrm{ng} / \mathrm{ml})$ and follicular $(4.3 \pm 1.0 \mathrm{ng} / \mathrm{ml})$ fluid in camels affected with ovarian hydrobursitis (Ali et al., 2011). Recently, all classes of ovarian follicles shared in pregnancy maintenance in pregnant camels by secreting more progesterone concentrations than follicles in non pregnant camels and the increase in follicle size the more progesterone concentration measured (El-Shahat et al., 2013).

During pregnancy, progesterone is probably produced by the corpus luteum and that the oestrogens are probably produced by the trophoblast (Skidmore et al., 1994, 1996). The increase in estradiol in pregnant camels of this study compared to non pregnant ones was reported also in llama (Leon et al., 1990) and is referred to the capacity for oestrogen production by the trophoblast (Wooding et al., 2003). Estradiol increased significantly from 11 month of pregnancy till parturition (Zhao et al., 1998). The contribution of ovarian follicles in secreting estradiol during pregnancy was lower than in non pregnant camels during their breeding season (El-Shahat et al., 2013).

Though testosterone is considered a male hormone, a small amount of testosterone is produced by the ovaries and the adrenal cortex. Testosterone levels are usually produced at low levels during pregnancy even in female camels. Testosterone, concentrations were significantly $(P<0.05)$ high during winter than other seasons of the year in non-pregnant camels (El-Harairy et al., 2010). It was reported that testosterone levels in non pregnant camels were found to follow the same variations as estrogen. Increased size of the follicle is accompanied by an increase in testosterone levels. Plasma testosterone levels increase from $50 \mathrm{pg} / \mathrm{ml}$, then declines with the regression of the follicle (Homeida et al., 1988). However within follicular fluid, the increase in follicle size was associated with a decrease in testosterone concentration whatever camels were pregnant or not (El-Shahat et al., 2013). Small ovarian follicles in pregnant camels had high testosterone levels compared to those of non pregnant ones (El-Shahat et al., 2013). Contrary to camels, high testosterone levels were

Egypt. J. Vet. Sci. Vol. 45-46 (2014 - 2015) 
recorded in non pregnant mares that failed to conceive (Abo El-Maaty et al., 2012). The equine species is characterized by its ability to convert strongly androgen-to-estrogen, principally by aromatase localized in follicular theca interna and granulosa cells (Sirois et al., 1991) and in the corpus luteum (Silberzahn et al., 1983). Testosterone the main endogenous anabolic androgen, is produced by the ovary of the cycling mare (Silberzahn et al., 1983) and by the corpus luteum in early pregnant mares (Daels et al., 1996).

\section{Thyroid hormones}

Since the main changes in thyroid function associated with the pregnant state are increased thyroid hormone requirements so these increased requirements can only be met by a proportional increase in hormone production that directly depends upon the availability of dietary iodine (Glinoer, 2003). In agreement with the results of the present work, triiodothyronine $\left(\mathrm{T}_{3}\right)$ and thyroxin $\left(\mathrm{T}_{4}\right)$ concentrations increased throughout pregnancy in dromedary camels (Heshmat $e t$ al.,1984 and Agrawal et al., 1989) and in Llama (Leon et al., 1990). However, lowest $\mathrm{T}_{3}$ and $\mathrm{T}_{4}$ values were observed during the tenth month in camels (Agrawal et al., 1989). In contrast to result of this study, $\mathrm{T}_{4}: \mathrm{T}_{3}$ ratio showed minor, non significant fluctuations during pregnancy (Agrawal et al., 1989). Total $\mathrm{T}_{4}$ and $\mathrm{T}_{3}$ concentrations increased markedly during the first and second trimesters in women (Chan et al., 1975) with a significant decrease in free $T_{3}$ and $\mathrm{T}_{4}$ in women at both weeks 14 and 32 of pregnancy compared to pre-pregnancy levels (Lof et al., 2005). During camel pregnancy, small and medium ovarian follicles had more $\mathrm{T}_{4}$ levels than large follicles but large follicle of non pregnant camels had more $T_{4}$ than other follicle classes and more than large follicles of pregnant camels (El-Shahat et al., 2013).

Significant low $\mathrm{T}_{4}$ level $(14.7 \pm 1.3 \mu \mathrm{g} / \mathrm{dl})$ was recorded in normal non pregnant dromedary camels compared to others with vaginal adhesions (Ali et al., 2010). In contrast to camels, thyroid hormones increased only during late pregnancy in the cow (Soliman et al., 1963, 1964). As well as, $\mathrm{T}_{4}$ concentrations did not vary substantially in pregnant goats then declines to a minimum concentration 1 day before parturition (Agrawal et al., 1985). In mares, neither thyroxin levels increased during pregnancy nor stage of pregnancy had significant effect (Katovich et al., 1974).

Although, Dixit et al. (1970) have reported a decrease in protein bound Iodine levels of camels with age, but there still numerous questions that needs clarification. Age had no significant effect on the serum concentration of $T_{3}$ and $\mathrm{T}_{4}$ in camels from 1to $>8$ years (Agarwal et al., 1986) and Turkoman horses (Nazifi et al., 2003). Moreover, Wasfi et al. (1987) and Agarwal et al. (1989) reported no correlation between thyroid hormones and age. Season (Khurana, \& Madan, 1986 and Yagil et al., 1978) but neither fetal sex (Agarwal et al., 1985) nor age of the dam (Shoda and Ishii, 1976) affected thyroid status. Similarly, thyroid hormone levels were not affected by failure of conception or by abortion

Egypt. J. Vet. Sci. Vol. 45-46 (2014 - 2015) 
(Agarwal et al., 1989). On the other hand, absence of any significant change in thyroid hormones of non pregnant camels or those that have aborted confirms that the fetal load does not alter the thyroid status of the animal to diagnostic levels (Agarwal et al.,1989).

The increase in thyroid hormones during early pregnancy observed in camels of this work may refer to the involvement of thyroid hormones in progesterone synthesis (Spicer et al., 2001, Nishimura et al., 2004) and lead us to suggest that luteal cells of mature corpora lutea may be involved in the synthesis of thyroid hormones, which may modulate progesterone synthesis, acting in an autocrine and paracrine way as in bovine (Mutinati et al., 2010).

The inverse correlation between thyroid hormones and estrogen observed here was also recorded in mares (unpublished data) and referred to that estrogens can alter the secretion rate and dynamics of thyroid hormones (Boccabella \& Alger, 1964, Yamada et al., 1966 and Chen \& Walfish, 1978). It seems that fluctuations in thyroid activity might be due to interactions with varying concentrations of estrogens and progesterone during pregnancy (Elias et al., 1984a).

\section{Conclusions}

Camels are not only differing from ruminant in their type of placenta but they are also mysterious in their endocrine profiles during pregnancy and are nearly similar to equine. Thyroid hormones play an important role during pregnancy in camels.

\section{References}

Abo El-Maaty, A.M., Shata, F.Y.H. and Gabr, F.I. (2012) Antioxidants markers, trace minerals and steroid hormones in preconceptional arab mares. Global Veterinaria, 9, 311-318.

Adam, C.L., Moir, C.E. and Shiach, P. (1989) Plasma progesterone concentrations in pregnant and non-pregnant llamas (Lama glama) Vet. Rec., 125, 618-620.

Agarwal, V.K., Agarwal, S.P., Kanoujia, A.S., Balain, D.S. and Dwaraknath, P.K. (1985) Thyroid hormones in preganant goats as related to litter size and fetal sex. $J$. Nucl. Agri. Biol., 14, 29-31.

Agarwal, S.P., Khanna, N.D., Agarwal, V.K. and Dwaraknath, P.K. (1986) Thyroid status of male camel during breeding and non-breeding seasons. Indian J. Anim. Sci., 56, 1036-1038

Agarwal, S.P., Khanna, N.D., Agarwal, V.K. and Dwaraknath, P.K. (1987) Circulating levels of estrogen and progesterone in female camel (Camelus dromedaries) during pregnancy. Theriogenology, 28, 849-858.

Egypt. J. Vet. Sci. Vol. 45-46 (2014 - 2015) 
Agarwal, S.P., Khanna, N.D., Agarwal, V.K. and Dwaraknath, P.K. (1989) Circulating concentrations of thyroid hormones in pregnant camels (Camelus dromedarius). Theriogenology, 31, 1239-1247.

Agarwal, S.P., Rai, A.K. and Khanna, N.D. (1992) Hormonal studies in postpartum female camels and their neonates. Theriogenology, 38, 735-747.

Alfuraiji, M.M. (1998) Concentrations of plasma oestradiol-17 $\beta$, progesterone and cortisol in preand postpartum stages of Arabian she-camel. Arab Gulf Journal of Scientific Research, 16, $173-182$.

Ali, A., Tharwat, M. and Al-sobayil, F.A. (2010) Hormonal, biochemical, and hematological profiles in female camels (Camelus dromedarius) affected with reproductive disorders Anim. Reprod. Sci., 118, 372-376.

Ali, A., Al-Sobayil, F.A., Tharwat, M. and Hassanein, K.M. (2011) Ovarian hydrobursitis in female camels (Camelus dromedaries): Biochemical, bacterial and protozoal evaluation. Theriogenology, 75, 734-741

Anouassi, A., Adnani, M. and Rae, E.l. (1992) Successful pregnancy following AI in camel requires induction of ovulation. First International Camel Symposium, 2-6 February 1992, Dubai, World Trade Centre, United Arab Emirates. pp. 175-178.

Ayoub, M.A., El-Khouly, A.A. and Mohamed, T.M. (2003) Some hematological and biochemical parameters and steroid hormone levels in the onehumped camel during different physiological conditions. Emirates Journal of Agricultural Science, 15, 44 - 45.

Babiker, E.A., Ahmed, A.I., Husna M.E. and Abdel-Aziz, B.E. (2011) Serum testosterone and progesterone levels and ovarian activity as indicators for seasonal breeding in dromedary camels in Sudan. Research Opinions In Animal \& Veterinary Sciences Roavs, 1, 309-312.

Bianco, A.C., Salvatore, D., Gereben, B., Berry, M.J. and Larsen, P.R. (2002) Biochemistry, cellular and molecular biology and physiological roles of the iodothyronine selenodeiodinases. Endocr. Rev. 23, 38-89.

Boccabella, A.V. and Alger, E.A. (1964) Influence of estradiol on thyroid: serum radioiodide concentration of gonadectomised and hypophysectomised rats. Endocrinology, 74, 680-688.

Chan, V., Paraskevaides, C.A. and Hale, J.F. (1975) Assessment of thyroid function during pregnancy. Br. J. Obstet Gynaecol., 82, 137-141.

Charkes, N.D. (1996) The many cause of subclinical hyperthyroidism. Thyroid., 6, 391-396.

Chen, B.X., Yuen, Z.X. and Pan, G.W. (1985) Semen-induced ovulation in the bactrian camel (Camelus bactrianus). J. Reprod. Fertil., 74, 335-339.

Chen, H.J. and Walfish, P.G. (1978) Effect of estradiol benzoate on thyroid-pituitary function in female rats. Endocrinology, 103, 1023-1030

Egypt. J. Vet. Sci. Vol. 45-46 (2014 - 2015) 
Daels, P.F., Chang, G.C., Hansen, B. and Mohammed, H.O. (1996) Testosterone secretion during early pregnancy in mares. Theriogenology, 45, 1211-1219

Dixit, V.P., Agarwal, V.K. and Nangia, O.P. (1970) Plasma protein bound iodinelevels in the camel. J. Endocrinol., 40, 463-464

El-Harairy, M.A., Zeidan, A.E.B., Afify, A.A., Amer, H.A. and Amer, A.M. (2010) Ovarian activity, biochemical changes and histological status of the dromedary shecamel as affected by different seasons of the year. Nature and Science, 8, 54-65

Elias, E., Bedark, E. and Yagil, R. (1984a) Peripheral blood levels of progesterone in female camels during various reproductive stags. Gen Comp Endocrinol 53, 235-240

Elias, E., Bedrak, E. and Yagil, R. (1984b) Estradiol concentration in the serum of the one-humped camel (Camelus dromedarius) during the various reproductive stages. Gen. Comp Endoct., 56, 258-264

El-Shahat, K.H., Abo El-Maaty, A.M. and Moawad, A.R. (2013) Follicular fluid composition in relation to follicular size in pregnant and non-pregnant dromedary camels (Camelus dromedaries). Anim. Reprod., 10 (1), 16-23.

El-Wishy, A.B. (1988) A study of the genital organs of the female dromedary (Camelus dromedarius). J. Reprod. Fertil., 82, 587-593.

Ghazi, F.B. (2007) Follicular wave pattern, folliculogenesis and assisted reproductive techniques in the non-pregnant female dromedary camel. Journal of Biological Sciences, 7, $1038-1045$.

Glinoer, D. (2003) Feto-maternal repercussions of iodine deficiency during pregnancy. An update. Ann Endocrinol (Paris). 64, 37-44.

Heshmat, H.A. Taha, A., Ismail, A.A. and Sami, M.B.A. (1984) Levels of thyroid hormones in the plasma of pregnant camels (Camelus dromedarius). Indian Journal of animal Sciences 54, 663-665

Homeida, A.M., Khalil, G.R. and Taha, A.A.M. (1988) Plasma concentrations of progesterone, oestrogens, testosterone and LH-like activity during the oestrus cycle of the (Camelus dromedarius). J. Reprod Fert, 83, 593-598.

Kakabakos, S.E. and Khosravi, M.J. (1992) Direct time-resolved fluorescence immunoassay of progesterone in serum involving the biotin-streptavidin system and the immobilized-antibody approach. Clin Chem. 38, 725-730.

Katovich, M., Evans, J.W. and Sanchez, O. (1974) Effects of season, pregnancy and lactation on thyroxin turnover in the mare. J. Anim. Sci., 38, 811-818.

Khurana, M.L. and Madan, M.L. (1986) Effect of stage of pregnancy on circulating thyroidal hormones among Karan-Swiss and Murrah animals. Indian J. Dairy Sci. 34,128-132 
Kozwich, D., Davis, G. and Sockol, D. (1991) Development of total Triiodothyronine enzyme immuonoassay in microtiter plate formate. Clin. Chem., 37,1040

Leon, J.B., Smith, B.B., Timm, K.I. and LeCren, G. (1990) Endocrine changes during pregnancy, parturition and the early post-partum period in the llama (Lama glama). J. Reprod Fertil., 88, 503-511.

Lof, M., Olausson, H., Bostrom, K., Janerot-Sjöberg, B., Sohlstrom, A. and Forsum, E. (2005) Changes in basal metabolic rate during pregnancy in relation to changes in body weight and composition, cardiac output, insulin-like growth factor I, and thyroid hormones and in relation to fetal growth. Am J. Clin Nutr., 81, 678-685.

Marie, M. and Anouassi, A. (1987) Induction of luteal activity and progesterone secretion in the non-pregnant one humped camel (Camelus dromedarius). J. Rerod. Fert., 80,183-192.

Martin, P.A. (2004) Reproductive patterns of Alpacas and Illamas, with reference to the Vicuna and Guanaco. In Text book McDonald's Veterinary Endocrinology and Reproduction Ed. By Pineda, M.H. and Dooley, M.P. Published by Iowa State Press , Iowa. pp. 523-546.

Mortimer, R.H., Landers, K.A., Balakrishnan, B., Li, H., Mitchell M.D., Patel, J. and Richard, K. (2012) Secretion and transfer of the thyroid hormone binding protein transthyretin by human placenta. Placenta., 33, 252-256.

Musa, B.E. and Abusineina, M.E. (1978) Clinical pregnancy diagnosis in the camel and a comparison with bovine pregnancy. Vet. Rec., 102, 7-10.

Mutinati, M., Desantis, S., Rizzo, A., Zizza, S., Ventriglia, G., Pantaleo, M. and Sciorsci, R.L. (2010) Localization of thyrotropin receptor and thyroglobulin in the bovine corpus luteum. Anim. Reprod. Sci., 118, 1-6.

Nazifi, S., Saeb, M. and Abedi, M. (2003) Serum lipid profiles and their correlation with thyroid hormones in clinically healthy Turkoman horses. Comp. Clin. Path., 12, 49-52

Nishimura, R., Shibaya, M., Skarzynski, D.J. and Okuda, K. (2004) Progesterone stimulation by LH involves the Phospholipase-C pathway in bovine luteal cells. $J$. Reprod. Dev., 50, 257-261.

Ratcliffe, W.A., Carter, G.D., Dowsett, M., Hillier, S.G., Middle, J.G. and Reed, M.J. (1988) Oestradiol assays: applications and guidelines for the provision of a clinical biochemistry service. Ann. Clin. Biochem., 25(4), 66-83.

Sanchez-Carbayo, M., Mauri, M., Alfayate, R., Miralles, C. and Soria, F. (1998) Elecsys testosterone assay evaluated. Clin. Chem., 44, 1744 -1746.

Shalash, M.R. and Nawito, M. (1963) Some aspects of sterility in the female camel. Dtsch Tierarztl Wochenschr., 70, 522-524.

Shoda, Y. and Ishii, T. (1976) Effect of season, pregnancy and lactation on serum thyroxine levels in dairy cattle. Japanese J. Zootech. Sci., 47, 659-664

Egypt. J. Vet. Sci. Vol. 45-46 (2014 - 2015) 
Silberzahn, P., Dehennin, L., Zwain, I.H. and Leymarie, P. (1983) Identification and measurement oftestosterone in plasma and follicular fluid of the mare,using gas chromatography-mass spectrometryassociated with isotope dilution. J. Endocrinol., 97, $51-56$.

Sirois, J., Kimmich, T.L. and Fortune, J.E. (1991) Steroidogenesis by equine preovulatory follicles: relative roles of theca interna and granulosa cells. Endocrinology, 128, 1159-1166.

Skidmore, J.A. (2005) Reproduction in dromedary camels: an update. Animal Reproduction, 2, 161 - 171

Skidmore, J.A., Allen, W.R. and Heap, R.B. (1994) Oestogen synthesis by the periimplantation conceptus of the one humped camel. Journal of Reproduction and Fertility 101, 363-371

Skidmore, J.A., Billah, M. and Allen, W.R. (1992) Ultrasonographic and videoendoscopic monitoring of early fetal development in the dromedary camel. In: Allen W.R. et al. Ed., Proc. First int. Camel Conf., Dubai, United Arab Emirates, 2-6 February 1982. Newmarket, UK, R. \& W. Publications, pp. 193-201.

Skidmore, J.A., Billah, M. and Allen, W.R. (1995) The ovarian follicular wave pattern in the mated and non-mated dromedary camel (Camelus dromedarius). J. Reprod. Fertil. Suppl., 49, 545-548.

Skidmore, J.A., Billah, M. and Allen, W.R. (1996) Patterns of hormone secretion through pregnancy in the one humped camel. Reproduction, Fertility and Development, 8, 868-869

Soliman, F.A., Nasr, H. and Zaki, K. (1963) Levels of thyroid and thyrotropic hormones in the blood of Friesian cows at various reproductive stages. J. Reprod. Fert., 6, 335-340.

Soliman, F.A., Zaki, K., Soliman, M.K. and Abdo, M.S. (1964) Thyroid function of Friesian cows during the oestrous cycle and in conditions of ovarian abnormality. Nature (Lond.) 204, 693-397

Spicer, L.J., Alonso, J. and Chamberlain, C.S. (2001) Effects of thyroid hormones on bovine granulosa and thecal cell function in vitro: dependence on insulin and gonadotropins. J. Dairy Sci., 84, 1069- 1076.

SPSS (2007) Statistical Package for Social Sciences, SPSS Inc., Chicago, IL, USA Copyright@for Windows, version 16.0 .

Sumar, J.B. (2000) Illamas and alpacas. In text book on Reproduction in Farm Animals, $7^{\text {th }}$ ed., Edited by B. Hafez and E.S.E. Hafez. Published by Lippincott Williams and Wilkins, Philadelphia,

Tibary, A. and Anouassi, A. (1996) Ultrasonographic changes of the reproductive-tract in the female camel (Camelus-Dromedarius) during the follicular cycle and pregnancy. J. Camel Practice and Res., 3, 71-90. 
Tibary, A. and Anouassi, A. (1997) Theriogenology in camelidae, Ist Edition, Ministry of Agriculture and Information, UAE, Dubai. Pp. 169-242.

Van Lennep, E.W. (1963) The placenta of the one humped camel during the second half of gestation Acta Morphologica Neerlandica Scandinavica, 6, 373-379.

Wang, H.S., Cheng, B.J. and Soong, Y.K. (1995) Insulin-like growth factor-I and insulin-like growth factor-binding protein-1 in Taiwanese women during normal pregnancy. J. Formos Med Assoc., 94, 698-70.

Wasfi, I.A., Hafez, A.M., Tayeb, F.M.A., Taher, A.Y., El-Tayeb, F.M.A. and ElTaher, A.Y. (1987) Thyroid hormones, cholesterol and triglyceride levels in the camel. Res Vet Sci., 42, 418

Wilson, R.T. (1989) Reproductive performance of the camel. The empirical base. Revue Elev. Méd. Vét. Pays Trop., 42, 117-125.

Wooding, F.B.P., Ozturk, M., Skidmore, J.A. and Allen, W.R. (2003) Developmental changes in localization of steroid synthesis enzymes in camelid placenta. Reproduction, 126, 239-247.

Yagil, R., Etzion, Z. and Ganani, J. (1978) Camel thyroid metabolism: Effect of season and dehydration. J. Physiol., 45,540-544.

Yamada, T., Takemura, Y., Kobayashi, I. and Shichijo, K. (1966) Re-evaluation of the effect of estrogen on thyroid activity in the rat and its mechanism. Endocrinology, 79, 849-857.

Zhao, X.X., Zhang,Y. and Chen, B.X. (1998) Serum progesterone and $17 \beta$-estradiol concentrations during pregnancy of Bactrian camel (Camelus bactrianus). Theriogenology, 50, 595-604. 


\section{هرمونات الغدة الدرقية والجنسية فى مصل اناث الابل (النوق)

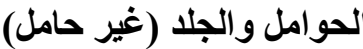

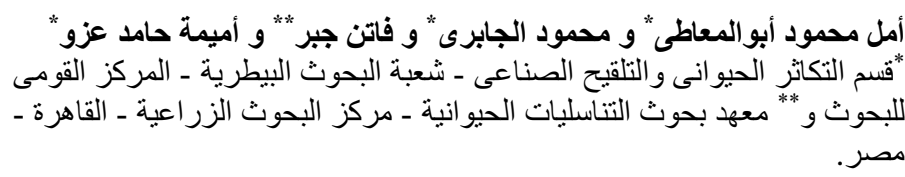

هذه الدراسة تصف الفروف فى مستوى هرمونات الغدة الدرقية والهرمونات

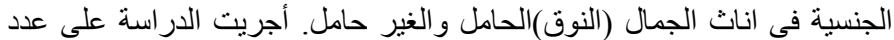

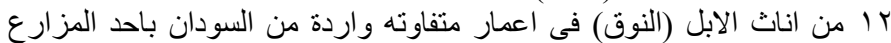

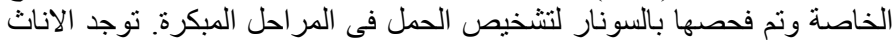

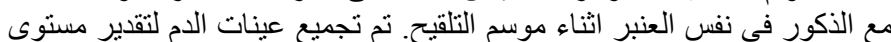

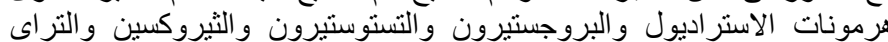

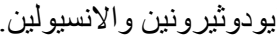

أشارت النتائج الى ارتفاع معنوى فى مستوى هرمونى و الثيروكسين و التراى الثي

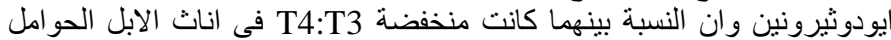

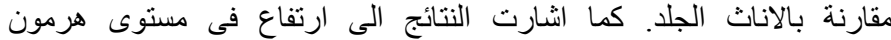

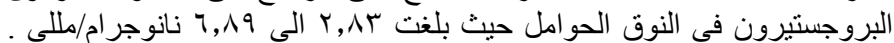

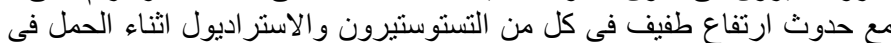

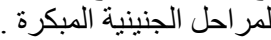

يستخلص من هذه الدراسة ان تقدير مستوى البروجستيرون فى الدم مايزال

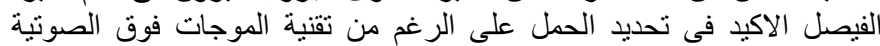

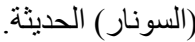

